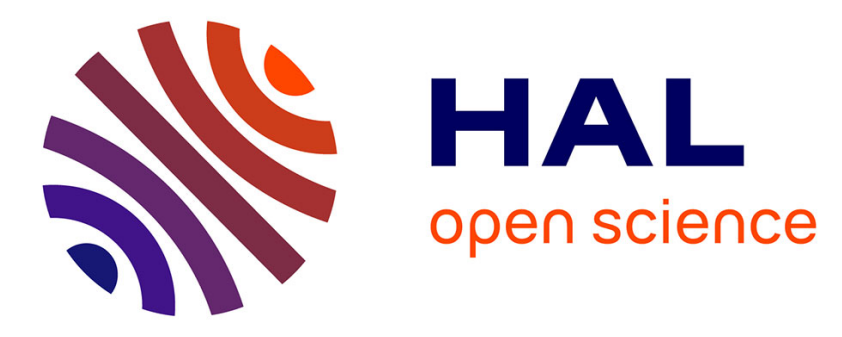

\title{
Social nutrition: an emerging field in insect science
}

Mathieu Lihoreau, Tamara Gómez-Moracho, Cristian Pasquaretta, James T.

Costa, Jerome Buhl

\section{To cite this version:}

Mathieu Lihoreau, Tamara Gómez-Moracho, Cristian Pasquaretta, James T. Costa, Jerome Buhl. Social nutrition: an emerging field in insect science. Current Opinion in Insect Science, 2018, 28, pp.73-80. 10.1016/j.cois.2018.05.003 . hal-02105098

\section{HAL Id: hal-02105098 \\ https://hal.science/hal-02105098}

Submitted on 20 Apr 2019

HAL is a multi-disciplinary open access archive for the deposit and dissemination of scientific research documents, whether they are published or not. The documents may come from teaching and research institutions in France or abroad, or from public or private research centers.
L'archive ouverte pluridisciplinaire HAL, est destinée au dépôt et à la diffusion de documents scientifiques de niveau recherche, publiés ou non, émanant des établissements d'enseignement et de recherche français ou étrangers, des laboratoires publics ou privés. 


\section{Accepted Manuscript}

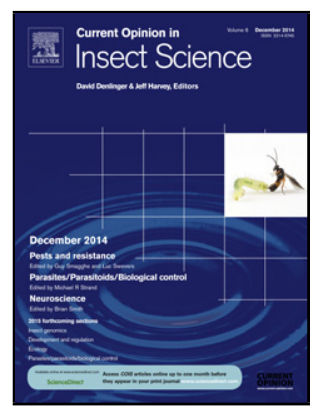

Title: Social nutrition: an emerging field in insect science

Authors: Mathieu Lihoreau, Tamara Gómez-Moracho, Cristian Pasquaretta, James T. Costa, Jerome Buhl

PII: $\quad$ S2214-5745(18)30050-6

DOI: $\quad$ https://doi.org/10.1016/j.cois.2018.05.003

Reference: $\quad$ COIS 463

To appear in:

Received date: $\quad$ 9-3-2018

Revised date: $\quad 1-5-2018$

Accepted date: $\quad 8-5-2018$

Please cite this article as: Lihoreau M, Gómez-Moracho T, Pasquaretta C, Costa JT, Buhl J, Social nutrition: an emerging field in insect science, Current Opinion in Insect Science (2018), https://doi.org/10.1016/j.cois.2018.05.003

This is a PDF file of an unedited manuscript that has been accepted for publication. As a service to our customers we are providing this early version of the manuscript. The manuscript will undergo copyediting, typesetting, and review of the resulting proof before it is published in its final form. Please note that during the production process errors may be discovered which could affect the content, and all legal disclaimers that apply to the journal pertain. 


\section{Social nutrition: an emerging field in insect science}

Mathieu Lihoreau ${ }^{\mathrm{a}, \star}$, Tamara Gómez-Moracho ${ }^{\mathrm{a}}$, Cristian Pasquaretta ${ }^{\mathrm{a}}$, James T. Costa $^{\mathrm{b}}$, Jerome Buhlc

aResearch Center on Animal Cognition (CRCA), Center for Integrative Biology (CBI); CNRS, University Paul Sabatier, Toulouse, France; mathieu.lihoreau@univ-tlse3.fr; tamara.gomez@univ-tlse3.fr; cristian.pasquaretta@univ-tlse3.fr.

bHighlands Biological Station, 265 N. Sixth Street, Highlands, NC 28741, USA and Department of Biology, Western Carolina University, Cullowhee, NC 28723, USA; costa@email.wcu.edu.

'School of Agriculture, Food and Wine, The University of Adelaide, Waite Campus, Southern Australia 5005, Australia; jerome.buhl@adelaide.edu.au.

* Corresponding author: Mathieu Lihoreau (mathieu.lihoreau@univ-tlse3.fr)

Special issue: "Social life in insects: can we get new insights from the "other" social insects?"

Article type: review

Short title: Insect social nutrition 


\section{Abstract}

Nutrition is thought to be a major driver of social evolution, yet empirical support for this hypothesis is scarce. Here we illustrate how conceptual advances in nutritional ecology illuminate some of the mechanisms by which nutrition mediates social interactions in insects and some other arthropods. We focus on experiments and models of nutritional geometry and argue that they provide a powerful means for comparing nutritional phenomena across species exhibiting various social ecologies. This approach, initially developed to study the nutritional behaviour of individual insects, has been increasingly applied to study insect groups and societies, leading to the emerging field of social nutrition. We discuss future directions for exploring how these nutritional mechanisms may influence major social transitions in insects and other animals.

\section{Keywords}

Insects, nutritional geometry, social interactions, social evolution, comparative analysis.

\section{Highlights}

- Nutrition mediates a wide range of social interactions.

- Nutritional geometry is a powerful means to study these effects.

- This approach was first developed to study individual insects.

- It is increasingly applied to groups and societies.

- Comparative research will clarify the role of nutrition in social evolution. 


\section{The geometry of insect nutrition}

Over the past few years, growing attention in insect social behaviour has been dedicated to non-eusocial species that nevertheless exhibit sophisticated interactions and group structures (e.g. [1-3], see also the article by Costa in this special issue). Diversifying the scope of insect behavioural research is essential to assess the full diversity of social forms and open new lines of research with the aim of understanding how different evolutionary pathways may lead to social life [4].

Nutrition, which encompasses behavioural strategies related to food selection, acquisition and processing, is a striking example. Many authors have identified food constraints as potential drivers for insect social evolution [5-8]. For instance the transition from ancestrally solitary cockroaches to social wood roaches and even eusocial termites may have evolved in response to the challenge of acquiring sufficient nitrogen from diets dominated by wood [7]. However these nutritional effects have remained difficult to quantify and compare across eusocial taxa, which has long hampered the development of a unifying theory [9]. Here we argue that conceptual advances used to study nutrition in solitary and gregarious insects provide such a framework.

Insects, like humans, carefully select foods and consume them in quantities and proportion that maximise fitness [10,11]. Important insights about insect nutrition come from nutritional geometry (Figs $1 \mathrm{~A}$ and $1 \mathrm{~B}$ ), a graphical modelling approach first developed by Stephen Simpson and David Raubenheimer to study dietary regulation behaviour by herbivorous locusts $[12,13]$ (for recent reviews see $[14,15]$ ). In nutritional geometry, foods are defined by their key dietary components (typically, but not exclusively, proteins and carbohydrates). Individuals are defined by their nutritional state (NS) and their intake target (IT; e.g. optimal state). In this approach, it is therefore possible to predict the blends of foods an insect should eat in order to acquire mixtures of nutrients maximising fitness traits, and to test these predictions in experimental conditions where animals are given artificial diets $[16,17]$.

Although initially applied to individual insects, nutritional geometry was recently extended to study the role of nutrition in social interactions (i.e. social nutrition) within groups and societies [18-20]. In this case, each individual has its own NS and attempts to reach an IT, either independently from the others (Fig. 1C) or by interacting socially or competitively (Fig. 1D). At the most basic level, animals may attract each other to feeding sites, potentially leading to collective foraging dynamics for nutrient balancing [21]. However more complex interactions may occur, as for instance in provisioning species, when adults must simultaneously choose foods to address their nutritional needs as well as the different needs of their offspring [22].

Here, we consider the emerging research field of social insect nutrition. We illustrate how nutritional geometry has been used to investigate some of the mechanisms that 
drive social interactions in a broad range of non-eusocial insects and some other invertebrates, and how this research increasingly motivates studies in eusocial insects. We discuss how comparing social phenomena based on the nutritional properties of groups (variance in NSs and ITs) may help delineate major principles by which nutrition influences social behaviour and evolutionary transitions.

\section{Collective behaviour}

Complex group dynamics often emerge through the repetition of simple social interactions [23]. In groups characterised by a low variance in NSs and ITs (Fig. 2A), nutrition can modulate these interactions and lead to collective movements.

\section{Mass migrations}

Outbreak orthopterans, such as locusts and crickets, exhibit mass migrations. In these insects, the homogenisation of the NSs of individuals (due to crowding) favours phenotypic changes and social interactions that trigger the onset of collective motion.

Short scale migrations of marching Mormon crickets (Anabrus simplex) and nymphs of desert locusts (Schistocerca gregaria) have been associated with a nutritional imbalance (or deficit in specific nutrients) $[24,25]$. During outbreaks, these insects congregate on receding vegetation patches [26], which in locusts induces a phenotypic shift from a solitarious to a gregarious phase. In these conditions of nutritional restriction, crickets [25] and locusts [27] seek out proteins (and mineral salts in the case of crickets) at concentrations matching those found in the tissues of conspecifics. By eating each other, insects can supplement their intake of nutrients that are limiting in the environment and increase their survival [28]. Cannibalistic interactions result in a push-pull mechanism in which insects move to reduce their risk of being eaten, while chasing ahead for potential victims, leading to the formation of marching bands at critical population densities [29,30]. Larger scale migrations of flying adults, however, have been associated with a nutritional balance [31]. In the Mongolian locust (Oedaleus asiaticus), adults artificially fed balanced (low-protein) diets have increased muscle size and fuel stores, and thus fly for longer than individuals fed imbalanced (very low- or high-protein) diets [31]. In the Eurasian steppe, heavy livestock grazing and grassland degradation (loss of organic N) promotes locust outbreaks by shifting plant nutrient content toward optimal lowprotein diets favourable to migratory morphs [32].

\section{Collective foraging}

Group foraging insects make collective decisions often enabling individuals to increase their probability to select good (if not the best) available options [33]. When resources are not nutritionally balanced, efficient foraging implies that groups alternate between exploiting multiple nutritionally complementary foods [14]. In such 
conditions, the homogenisation of the NSs of individuals (due to social cohesion and collective feeding) generates collective patterns for nutrient regulation.

Fruit flies (Drosophila melanogaster) self-select foods in order to balance their intake of protein and carbohydrates [16,34]. Under high population densities, these insects respond to an aggregation pheromone mediating collective foraging decisions [35]. If given the task to find a balanced diet among several imbalanced diet options, groups of flies outperform single flies, indicating that social interactions enhance individual choices [36]. In such conditions, collective feeding synchronises the NS of all individuals, which generates collective switching between complementary diets $[18,19]$. In the nomadically foraging forest tent caterpillar (Malacosoma disstria), where social foraging involves trail following and social cohesion is therefore stronger, group foraging can lead to suboptimal nutritional decisions by which the individuals settle on the first food patch discovered [37]. Presumably, the limited tree-wide searching and short-distance recruitment of $M$. disstria reflects more of a group cohesion function that constrains location of high-quality patches and the nutrition of individuals in laboratory conditions, in contrast to the collective flexibility in social foraging exhibited by its central-place foraging congener $M$. americanum. Nutritional geometry models predict that different levels of social attraction can enhance individual decisions in environments with different food abundances and spatial distributions [38], suggesting that the suboptimal behaviours that can be observed in experimental conditions may be more adapted to natural conditions.

\section{Nutritional immunology}

Parasites, pathogens and commensals can all modify the IT of an insect, ultimately influencing its feeding decisions [39]. These effects can generate a high variance in ITs among group members and affect collective dynamics (Fig. 2B).

\section{Self-medication}

Insects exposed to parasites often change their feeding preferences, seeking out substances to overcome the infection. While best-described cases of self-medication involve the consumption of toxic minerals or secondary compounds [40], nutrient intake can also influence the immune response of insects and help them combat parasites [41-43]. The clearest evidence come from the African armyworm (Spodoptera exempta), an outbreak moth whose larvae feed on graminaceous plants [44]. Caterpillars fed high-protein diets are more likely to survive a baculovirus infection than caterpillars fed low-protein diets [43]. Accordingly, virus-challenged caterpillars given a choice between complementary diets eat more protein than controls [43]. A similar switch of dietary preferences has been modelled to explore the possibility of collective medication in eusocial insect colonies, whereby foragers adjust their nutrient collection to the ITs of infected (higher in protein) and noninfected nestmates [45]. In such social groups, large variance in ITs (due to different 
infection statuses among individuals) may generate complex dietary regulatory patterns. Although there is not direct demonstration of dietary collective medication in eusocial insects, honey bees (Apis mellifera) infected with the microsporidium Nosema ceranae tend to collect and eat pollens that are richer in protein, which increases their survival $[46,47]$.

\section{Gut microbiota}

Many insects are nutritionally and immunologically dependent on symbiotic microbes [48]. An individual's diet influences its microbiota [49], which can in turn affect host physiology and behaviour, including food decisions [50] and social interactions [51]. In a host group, different microbiota communities can generate large variance in the ITs of individuals, potentially leading to collective patterns of nutrient regulation. In the fruit fly ( $D$. melanogaster), microbes found in the food modify individual nutritional decisions [50]. When offered a choice between different diets, microbe-free flies choose a nutritionally balanced diet, whereas flies artificially supplemented with microbes tend to choose slightly imbalanced diets (high-protein or high-carbohydrate), depending on which microbes the flies were associated with [50]. Seeding diets with microbes further influences these foraging patterns, leading flies to trade-off between balancing nutrient acquisition and acquiring beneficial symbionts [50]. Interestingly, flies artificially supplemented with commensal bacteria do not express any negative symptoms following deprivation of essential dietary amino acids, indicating that microbes can also compensate for a nutritional imbalance [52].

\section{Inter-individual behavioural variability}

Advanced societies are characterised by some level of behavioural variability, sometimes leading to division of labour. In a group, differential access to nutrients among individuals can generate a high variance in NSs, underpinning behavioural variability (Fig. $2 \mathrm{C}$ ).

\section{Temporary roles}

Socially foraging insects often alternate between feeding and moving phases in a coordinated manner [23]. In such groups, variance in the NSs of individuals can regulate the behavioural transition, whereby individuals with the greatest nutrient imbalance initiate feeding and lead groups. In the nomadic forest tent caterpillar ( $M$. disstria), which forms foraging trails of dozens of individuals, most protein-deficient individuals tend to initiate collective departure and lead the group towards new feeding sites, whereas protein-satiated individuals follow behind [53]. Theoretically, this nutritional regulation of temporary roles can lead to collective patterns where the decisions to switch from one food to another nutritionally complementary food may emerge through natural variation in the NS among leaders (most imbalanced state individuals) and followers (most balanced states individuals) [19]. 


\section{Reproductive division of labour}

In addition to mediating temporary roles, differential nutrition generates variance in the NSs of individuals that can be associated with reproductive division of labour where only a subset of the individuals can reach their IT and become either dominant [54] or breeder [55]. Social spiders of the genus Stegodyphus form colonies in which less than half of the females reproduce. These spiders share large webs that allow them to capture bigger prey, but the largest females tend to monopolize limited nutritional resources required for growth and reproduction [56]. When artificially supplemented with lipid-rich prey, colonies produce higher proportions of reproductive breeders relative to non reproductive helpers, indicating that lipids determine the magnitude of reproductive skews in this species [57]. In more advanced societies, differential feeding, whereby adults selectively allocate nutrients to the larvae, has also been implicated in regulating the development of reproductive castes (e.g. eusocial hymenoptera [58], termites [7]). In the honeybee (A. mellifera), larvae fed royal jelly, honey and pollen develop into sterile workers, while larvae exclusively fed royal jelly develop into queens [59]. Similar effects have been observed in solitary bees (Megachile rotundata) suggesting that nutritionally regulated reproductive plasticity is an ancestral condition that facilitated social evolution in bees [60].

\section{Foraging for others}

Food provisioning implies that some individuals need to collect foods that address the divergent needs of multiple other individuals. In such groups, characterised by a high variance in NSs and a high variance in ITs (Fig. 2D), nutritional interactions can lead to complex foraging patterns.

\section{Oviposition site decisions}

When the nutrition of juveniles depends on parents, adults must make foraging decisions that simultaneously address their own IT as well as the different ITs of their progeny. At the most basic level, a female may choose to lay eggs in site providing good nutrition to the larvae. Female fruit flies ( $D$. melanogaster) eat and lay eggs in decaying fruits. When selecting a food source, flies must therefore integrate decisions about feeding (individual nutrition) and egg laying (offspring nutrition). Flies given a choice between artificial diets varying in concentration and ratios of protein to carbohydrates exhibit complex food visitation dynamics, alternating between laying eggs on high-carbohydrate diets and feeding on different diets depending on their NS [36]. Although larvae show faster development when reared on high-protein diets, they survive better and reach higher learning performances on diets with more balanced protein to carbohydrate ratios [36]. The apparent mismatch between the oviposition preference of females for high-carbohydrate diets and the high performance of larvae on balanced diets reflects a natural situation were high- 
carbohydrate decaying fruits become enriched in high-protein yeast as they start rotting, yielding optimal nutrition for the developing larvae [61], suggesting that females select oviposition sites based on sensory cues predicting good larval nutrition.

\section{Colony-level nutrition}

In eusocial insects, foragers need to satisfy the ITs of all colony members, including themselves, the non-foraging workers, as well as the larvae and the queens, which have significantly higher protein needs [62]. Early applications of nutritional geometry in ants show that colonies dynamically regulate their protein to carbohydrate intake at a colony level IT [63] that can vary with colony composition [64]. If constrained to high-protein diets, ants reject excess protein in the form of pellets stockpiled in a waste dump outside the nest, which signals a need for carbohydrates to the foragers [64]. In these insects, variation in the ITs among castes modulate the complex network of social interactions within the colony including food assessment, collection, processing, storage and waste disposal [14]. Studies on bees show how colonies also balance their intake of free amino acids in nectar, and lipids and proteins in pollen, with important implications for understanding pollinator population declines [59]. For instance, honey bee colonies ( $A$. mellifera) constrained to pollen deficient in one essential amino acid subsequently allocate more foragers towards the complementary diet in a choice test [65].

\section{Farming}

Some ants and termites farm ectosymbiontic fungi that turn nutrients into digestible food for the insects. Here, the divergence in the ITs of insects and the ITs of their cultivars structures the collective foraging pattern of colonies. In Mycocepurus smithii ants, for instance, fungal cultivars have conserved their capacity for independent reproduction [66]. Mapping fungus performance in a nutrient space revealed that the growth of edible somatic tissues and non-edible reproductive tissues are maximised on high-carbohydrate diets, but that modest protein provisioning can suppress reproductive tissues [66]. When given a choice between artificial diets, ants collect protein and carbohydrates in amounts and ratios that promote (but do not maximise) growth of fungal somatic tissues while inhibiting production of reproductive tissues to values that are consistent with field measures [67]. This nutritional control by ants reflects their need to curtail potential host-symbiont conflict over the independent reproduction of fungi.

\section{Future directions}

In this short review we have illustrated how nutrition impacts on many forms of social interactions and how these effects can be studied experimentally and theoretically using nutritional geometry. This conceptual framework is increasingly used to compare social interactions in insects exhibiting various levels of social complexity 
and provides a powerful basis for comparative research on the mechanisms by which nutrition affects social interactions and their evolution, in order to fill a major gap in insect science.

As proposed in Fig. 2, using the nutritional characteristics of social groups is an objective approach to quantify and compare the effects of nutrition on social behaviour. Comparative research on insect social behaviour has suffered from a priori criteria to classify social levels, sometimes misleading about the real complexity of the social interactions exhibited by species [68]. Natural selection is expected to act on the intake targets of individuals [69] and therefore to shape the variance in intake targets within groups and societies [19]. Understanding social behaviour in groups with comparable nutritional structures (in terms of diversity of nutritional states and needs), can reveal the specific effects of nutrition on social behaviour, especially as we progress from populations of solitary individuals to more integrated societies. Importantly, both the variance of nutritional states and the variance of intake targets within a group can be modelled (e.g. Fig. 1) and experimentally quantified and manipulated, thereby providing ample opportunities to generate and test predictions in a wide range of species [14]. Models of nutritional geometry have already been used to explore the evolution of nutritional behaviours $[19,20]$. For instance, social foraging, mediated by varying levels of social attraction and alignments, is expected to be most adaptive in environments where food resources are imbalanced, abundant but recalcitrant, nutritionally rich but ephemeral, or patchily distributed, whereas solitary foraging should be favoured when food is dispersed [38], a result in line with theories about the evolution of food recruitment in eusocial insects [70]. Future work should explicitly include selection processes to generate scenarios by which nutrition may favour evolutionary transitions between different social forms.

The field of social nutrition is still in its infancy and many mechanisms by which nutrition shapes social interactions still remain to be discovered. Simple societies can teach us a lot about social behaviour and motivate important research in more advanced societies, as illustrated by fast growing research on social bee nutrition $[59,71]$. Since basic features of nutritional biology are shared by virtually all animal species, including humans [72], this approach has implications beyond just the insect sciences [73], and may provide key insights to study the broader role of nutrition in the evolution of animal societies .

\section{Conflict of interest}

None declared.

\section{Acknowledgements}


We thank Sandra Steiger and Joël Meunier for the invitation to contribute to this special issue of Current Opinion in Insect Science. We are also grateful to two anonymous reviewers for their useful comments on a previous version of the manuscript.

\section{Funding}

ML was funded by the Centre national de la Recherche Scientifique (CNRS), and grants from the Initiative d'Excellence (IDEX) of the Federal University of Toulouse and the Agence Nationale de la Recherche (ANR-16-CE02-0002-01). TGM was funded by a postdoctoral fellowship from the Fyssen Foundation. CP was funded by the Initiative d'Excellence (IDEX) of the Federal University of Toulouse. JTC was supported by the Highlands Biological Station and Western Carolina University. JB was funded by an Australian Research Council (ARC) Linkage Project (LP150100479).

\section{References and recommended reading}

1. Halloy J, Sempo G, Caprari G, Rivault C, Asadpour M, Tâche F, Saïd I, Durier V, Canonge $S$, Amé JM, et al.: Social integration of robots into groups of cockroaches to control self-organized choices. Science 2007, 318:1055-1058.

2. Battesti M, Moreno C, Joly D, Mery F: Spread of social information and dynamics of social transmission within Drosophila groups. Curr Biol 2012, 22:309313.

3. Ramdya P, Lichocki P, Cruchet S, Frisch L, Tse W, Floreano D, Benton R: Mechanosensory interactions drive collective behaviour in Drosophila. Nature 2014, 519:233-6.

4. $\quad$ Costa JT: The Other Insect Societies. Harvard University Press; 2006.

5. Amdam GV, Norberg K, Fondrik MK, Page RE: Reproductive ground plan may mediate colony-level selection effects on individual foraging behavior in honey bees. Proc Natl Acad Sci USA 2004, 79:973-980.

6. Hunt $\mathrm{JH}$, Amdam GV: Bivoltinism as an antecedent to eusociality in the paper wasp genus Polistes. Science 2005, 308:264-267.

7. Nalepa CA: Origin of termite eusociality: trophallaxis integrates the social, nutritional, and microbial environments. Ecol Entomol 2015, 40:323-335.

8. Toth AL, Robinson GE: Worker nutrition and division of labour in honeybees. Anim Behav 2005, 69:427-435.

9. Hunt JH, Nalepa CA: Nourishment and Evolution in Insect Societies. Westview press; 1994.

10. Behmer ST: Insect herbivore nutrient regulation. Ann Rev Entomol 2009, 54:165-87.

11. Simpson SJ, Clissold FJ, Lihoreau M, Ponton F, Wilder SM, Raubenheimer D: Recent advances in the integrative nutrition of arthropods. Annu Rev Entomol 2015, 60:293-311.

12. Simpson SJ, Raubenheimer D: A multi-level analysis of feeding behaviour: the geometry of nutritional decisions. Phil Trans $R$ Soc $B$ 1993, 342:381-402.

13. Raubenheimer D, Simpson SJ: The geometry of compensatory feeding in the locust. Anim Behav 1993, 45:953-964. 
- This paper introduces the main concepts of nutritional geometry and applies them to the study of nutrient balancing strategies in locusts.

14. Simpson SJ, Raubenheimer D: The Nature of Nutrition: a Unifying Framework from Animal Adaptation to Human Obesity. Princeton University Press; 2012.

- This is a reference book reviewing 20 years of research on nutritional geometry and its broader applications in various fields such as animal behaviour, ecology, conservation, human health and farming.

15. Raubenheimer D, Simpson SJ: Nutritional ecology and foraging theory. Curr Opin Insect Sci 2018, 27:1-8.

16. Lee KP, Simpson SJ, Clissold FJ, Brooks R, Ballard JWO, Taylor PW, Soran N, Raubenheimer D: Lifespan and reproduction in Drosophila: new insights from nutritional geometry. Proc Natl Acad Sci USA 2008, 105:2498-2503.

- This paper introduces fitness landscapes, an approach that is now widely used to map the performance of animals given different balances and amounts of nutrients in order to empirically identify their intake targets. This study is important because it shows that nutrient balance (not caloric intake) is the important parameter determining fitness traits.

17. Rapkin J, Jensen K, Archer CR, House CM, Sakaluk SK, del Castillo E, Hunt J: The geometry of nutrient space-based life-history trade-offs: sex-specific effects of macronutrient intake on the trade-off between encapsulation ability and reproductve effort in decorated crickets. Am Nat 2018, 191.

18. Lihoreau M, Buhl J, Charleston MA, Sword GA, Raubenheimer D, Simpson SJ: Modelling nutrition across organizational levels: from individuals to superorganisms. J Insect Physiol 2014, 69:2-11.

19. Lihoreau M, Buhl J, Charleston MA, Sword GA, Raubenheimer D, Simpson SJ: Nutritional ecology beyond the individual: a conceptual framework for integrating nutrition and social interactions. Ecol Lett 2015, 18:273-286.

- This paper introduces an individual-based model integrating concepts of nutritional geometry and collective animal behaviour to study the role of nutrition in mediating social interactions (i.e. social nutrition).

20. Simpson SJ, Raubenheimer D, Charleston MA, Clissold FJ: Modelling nutritional interactions: from individuals to communities. Trends Ecol Evol 2010, 25:53-60.

21. Senior AM, Lihoreau M, Charleston MA, Buhl J, Raubenheimer D, Simpson SJ: Adaptive foraging in groups with conflicting nutritional needs. R Soc Open Sci 2016, 3:150638.

22. Dussutour A, Poissonnier LA, Buhl J, Simpson SJ: Resistance to nutritional stress in ants: when being fat is advantageous. J Exp Biol 2016, 219:824-833.

23. Sumpter DJT: Collective Animal Behaviour. Princeton University Press; 2010.

24. Bazazi S, Buhl J, Hale JJ, Anstey ML, Sword GA, Simpson SJ, Couzin ID: Collective motion and cannibalism in locust migratory bands. Curr Biol 2008, 18:735-739.

25. Simpson SJ, Sword GA, Lorch PD, Couzin ID: Cannibal crickets on a forced march for protein and salt. Proc Natl Acad Sci USA 2006, 103:4152-4156.

- This paper was the first to demonstrate the influence of nutrition on social behaviour using nutritional geometry, showing how protein and salt deprivation triggers mass migrations in Mormon crickets. It also shows how nutritional geometry can contribute to field research.

26. Collett M, Despland E, Simpson SJ, Krakauer DC: Spatial scales of desert locust gregarization. Proc Natl Acad Sci USA 1998, 95:13052-13055.

27. Bazazi S, Romanczuk P, Thomas S, Schimansky-Geier L, Hale JJ, Miller GA, Sword 
GA, Simpson SJ, Couzin ID: Nutritional state and collective motion: from individuals to mass migration. Proc $R$ Soc $B$ 2011, 278:356-363.

28. Hansen M, Buhl J, Bazazi S, Simpson SJ, Sword GA: Cannibalism in the lifeboat collective movement in Australian plague locust. Behav Ecol Sociobiol 2011, 65:1715-1720.

29. Buhl J, Sumpter DJT, Couzin ID, Hale JJ, Despland E, Miller ER, Simpson SJ: From disorder to order in marching locusts. Science 2006, 312:1402-1406.

30. Guttal V, Romanczuk P, Simpson SJ, Sword GA, Couzin ID: Cannibalism can drive the evolution of behavioural phase polyphenism in locusts. Ecol Lett 2012, 15:1158-66.

31. Cease AJ, Harrison JF, Hao S, Niren DC, Zhang G, Kang L, Elser JJ: Nutritional imbalance suppresses migratory phenotypes of the Mongolian locust (Oedaleus asiaticus). R Soci Open Sci 2017, 4:161039.

32. Cease AJ, Elser JJ, Ford CF, Hao S, Kang L, Harrison JF: Heavy livestock grazing promotes locust outbreaks by lowering plant nitrogen content. Science 2012, 335:467-469.

33. Beckers R, Deneubourg JL, Goss S, Pasteels JM: Collective decision making through food recruitment. Insectes Soc 1990, 37:258-267.

34. Piper MDW, Blanc E, Leitao-Gonçalves R, Yang M, He X, Linford NJ, Hoddinott MP, Hopfen C, Soultoukis GA, Niemeyer C, et al:: A holidic medium for Drosophila melanogaster. Nat Meth 2014, 11:100-105.

35. Lihoreau M, Clarke IM, Buhl J, Sumpter DJT, Simpson SJ: Collective selection of food patches in Drosophila. J Exp Biol 2016, 219:668-675.

36. Lihoreau M, Poissonnier LA, Isabel G, Dussutour A: Drosophila females trade off good nutrition with high quality oviposition sites when choosing foods. J Exp Biol 2016, 219:2514-2524.

37. Dussutour A, Simpson SJ, Despland E, Colasurdo N: When the group denies individual nutritional wisdom. Anim Behav 2007, 74:931-939.

38. Lihoreau M, Charleston MA, Senior AM, Clissold FJ, Raubenheimer D, Simpson SJ, Buhl J: Collective foraging in spatially complex nutritional environments. Phil Trans R Soc B 2017, 372:20160238.

- This paper integrates individual-based modelling of nutritional geometry and spatial ecology to study the nutritional behaviour of animal groups in large heterogeneous environments containing foods with different abundance, patchiness and nutritional composition.

39. Wong AC-N, Holmes A, Ponton F, Lihoreau M, Wilson K, Raubenheimer D, Simpson SJ: Behavioral microbiomics: a multi-dimensional approach to microbial influence on behaviour. Front Microbiol 2015, 6:1359.

40. de Roode JC, Lefèvre T, Hunter MD: Self-medication in animals. Science 2013, 340:150-151.

41. Lee KP, Cory JS, Wilson K, Raubenheimer D, Simpson SJ: Flexible diet choice offsets protein costs of pathogen resistance in a caterpillar. Proc $R$ Soc $B$ 2006, 273:823-829.

42. Povey S, Cotter SC, Simpson SJ, Lee KP, Wilson K: Can the protein costs of bacterial resistance be offset by altered feeding behaviour? J Anim Ecol 2009, 78:437-446.

43. Povey S, Cotter SC, Simpson SJ, Wilson K: Dynamics of macronutrient selfmedication and illness-induced anorexia in virally infected insects. J Anim Ecol 2014, 83:245-255. 
44. Graham RI, Grzywacz D, Mushobozi WL, Wilson K: Wolbachia in a major African crop pest increases susceptibility to viral disease rather than protects. Ecol Lett 2012, 15:993-1000.

45. Poissonnier LA, Lihoreau M, Gomez Moracho T, Dussutour A, Buhl J: A theoretical exploration of dietary collective medication in social insects. $J$ Insect Physiol 2017,

46. Tritschler M, Vollmann JJ, Yanez O, Chejanovsky N, Crailsheim K, Neumann P: Protein nutrition governs within-host race of honey bee pathogens. Sci Rep 2017, 7:14988.

47. Ferguson JA, Northfield TD, Lach L: Honey bee (Apis mellifera) pollen foraging reflects benefits dependent on individual infection status. Microb Ecol 2018, doi:10.1007/s00248-018-1147-7.

48. Douglas AE: The Symbiontic Habit. Princeton University Press; 2010.

49. Huang XF, Chaparro JM, Reardon KF, Judd TM, Vivanco JM: Supplementing blends of sugars, amino acids, and secondary metabolites to the diet of termites (Reticulitermes flavipes) drive distinct gut bacterial communities. Microb Ecol 2016, 72:497-502.

50. Wong ACN, Wang QP, Morimoto J, Senior AM, Lihoreau M, Neely GG, Simpson SJ: Gut microbiota modifies olfactory-guided microbial preferences and foraging decisions in Drosophila. Curr Biol 2017, 27:2397-2404.

51. Wada-Katsumata A, Zurek L, Nalyanya G, Roelofs WL, Zhang A, Schal C: Gut bacteria mediate aggregation in the German cockroach. Proc Natl Acad Sci USA 2015, 112:15678-15683.

52. Leitão-Gonçalves R, Carvalho-Santos Z, Francisco AP, Anjos M, Baltazar C, Elias AP, Itskov PM, Piper MDW, Ribeiro C: Commensal bacteria and essential amino acids control food choice behavior and reproduction. PLoS Biol 2017, 15:e2000862.

53. McClure M, Ralph M, Despland E: Group leadership depends on energetic state in a nomadic collective foraging caterpillar. Behav Ecol Sociobiol 2011, 65:15731579.

54. Senior AM, Lihoreau M, Buhl J, Raubenheimer D, Simpson SJ: Social network analysis and nutritional behavior: an integrated modeling approach. Frontiers Psychol 2016, 7:18.

55. Senior AM, Charleston MA, Lihoreau M, Buhl J, Raubenheimer D, Simpson SJ: Evolving nutritional strategies in the presence of competition: a geometric agentbased model. PLoS Comp Biol 2015, 11:e1004111.

- This paper introduces evolutionary algorithms to individual-based models of nutritional geometry for exploring the evolution of social behaviour based on nutritional constraints.

56. Lubin Y, Bilde T: The evolution of sociality in spiders. Adv Stud Behav 2007, 37:83-145.

57. Salomon M, Mayntz D, Lubin Y: Colony nutrition skews reproduction in a social spider. Behav Ecol 2008, 19:605-611.

- This paper uses nutritional geometry and dietary manipulation to demonstrate the influence of key nutriments (lipids) in the regulation of reproductive division of labour in spiders.

58. Judd TM, Teal PEA, Hernandez EJ, Choudhury T, Hunt JH: Quantitative differences in nourishment affect caste-related physiology and development in the paper wasp Polistes metricus. PLoS One 2015, 10:e0116199.

59. Wright GA, Nicolson SW, Shafir S: Nutritional physiology and ecology of honey 
bees. Annu Rev Entomol 2018, 63:327-344.

60. Fischman BJ, Pitts-Singer TL, Robinson GE: Nutritional regulation of phenotypic plasticity in a solitary bee (Hymenoptera: Megachilidae). Environ Entomol 2017, 46:1070-1079.

61. Matavelli C, Carvahlo MJA, Martins NE, Mirth CK: Differences in larval nutritional requirements and female oviposition preference reflect the order of fruit colonization of Zaprionus indianus and Drosophila simulans. J Insect Physiol 2015, 82:66-74.

62. Cassill DL, Tschinkel WR: Regulation of diet in the fire and, Solenopsis invicta. J Insect Behav 1999, 12:307-328.

63. Cook SC, Eubanks MD, Gold RE, Behmer ST: Colony-level macronutrient regulation in ants: mechanisms, hoarding and associated costs. Anim Behav 2010, 79:429-437.

64. Dussutour A, Simpson SJ: Communal nutrition in ants. Curr Biol 2009, 19:740744.

- This paper introduces nutritional geometry for studying eusocial insects and describes how ants collectively maintain nutritional homeostasis by adjusting their nutrient collection to a colony level intake target.

65. Hendriksma HP, Shafir S: Honey bee foragers balance colony nutritional deficiencies. Behav Ecol Sociobiol 2016, 70:509-517.

66. Rabeling C, Gonzales O, Schultz TR, Bacci MJ, Garcia MV, Verhaagh M, Ishak HD, Mueller UG: Cryptic sexual populations account for genetic diversity and ecological success in a widely distributed, asexual fungus-growing ant. Proc Natl Acad Sci USA 2011, 108:12366-71.

67. Shik JZ, Gomez EB, Kooij PW, Santos JC, Wcislo WT, Boomsma JJ: Nutrition mediates the expression of cultivar-farmer conflict in a fungus-growing ant. Proc Natl Acad Sci USA 2016, 113:10121-10126.

- This paper uses nutritional geometry to study nutritional interactions between species, here the complex interactions between a social insect host and its fungus ectosymbiont.

68. Costa JT, Fitzgerald TD: Social terminology revisited: where are we ten years later? Annales Zoologici Fennici 2005, 42:559-564.

69. Simpson SJ, Sibly RM, Lee KP, Behmer ST, Raubenheimer D: Optimal foraging when regulating intake of multiple nutrients. Anim Behav 2004, 68:1299-1311.

70. Dornhaus A, Chittka L: Evolutionary origins of bee dances. Nature 1999, 401:38.

71. Klein S, Cabirol A, Devaud JM, Barron AB, Lihoreau M: Why bees are so vulnerable to environmental stressors. Trends Ecol Evol 2017, 32:268-278.

72. Raubenheimer D, Simpson SJ: Nutritional ecology and human health. Annu Rev Nutr 2016, 36:603-626.

73. Strang S, Hoeber C, Uhl O, Koletzko B, Münte TF, Lehnert H, Dolan RJ, Schmid SM, Park SQ: Impact of nutrition on social decision making. Proc Natl Acad Sci USA 2017, 114:6510-6514. 


\section{Figures}
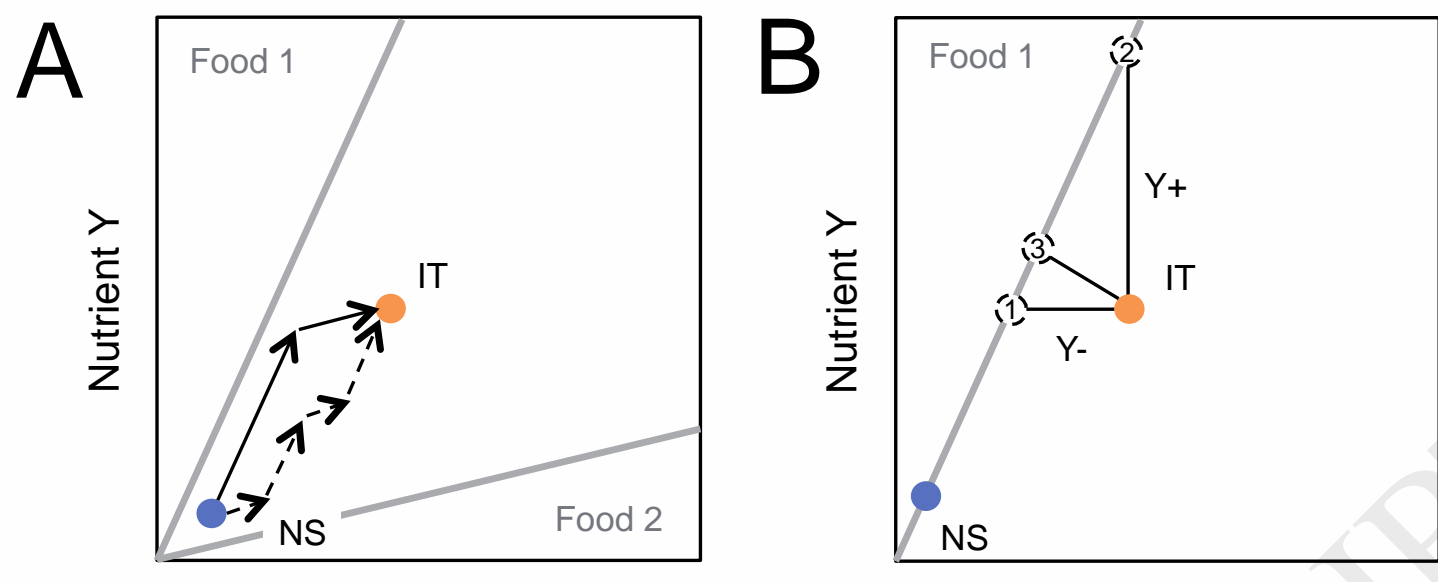

Nutrient $\mathrm{X}$

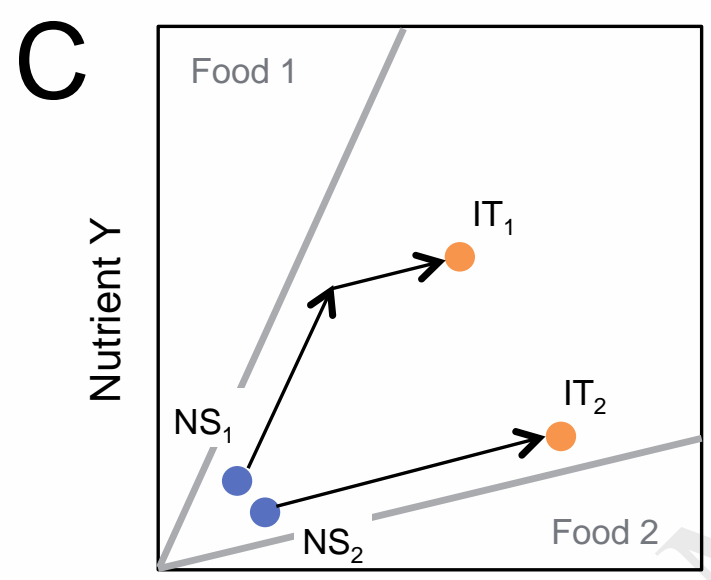

Nutrient X

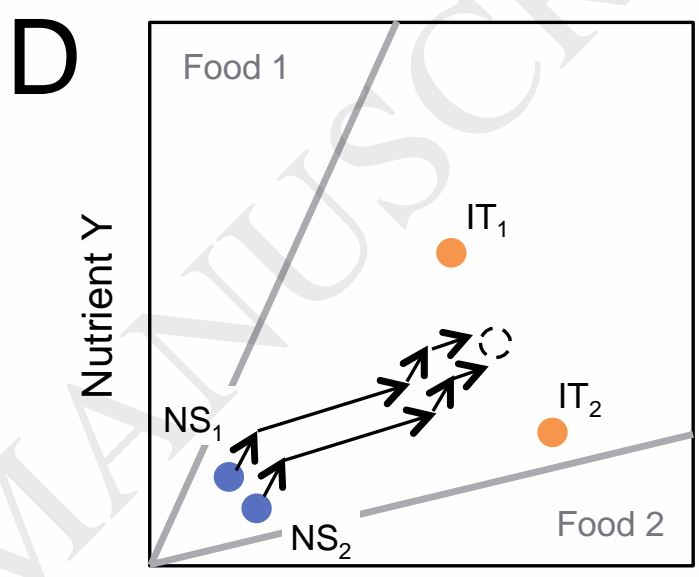

Nutrient $X$

Fig 1. Examples of nutritional geometry models for hypothetical individuals ( $A$ and $B$ ) and groups $(C$ and $D)$. A. Nutritional rails (grey lines) represent the ratio of nutrients $X$ and $Y$ in foods. The blue dot is the nutritional state (NS) of the individual and the red dot is its intake target (IT). Foods 1 and 2 are individually imbalanced but complementary (fall on opposite sides of the IT). The individual can reach its IT by combining its intake from the two foods (arrows). B. The individual is restricted to a single imbalanced food and can: (1) satisfy its needs for $Y$ but suffer a shortfall of $X$; (2) satisfy its needs for $X$ but over-ingest $Y$; (3) suffer a moderate shortage of $X$ and excess of $Y$. C. The two individuals have different NSs $\left(N S_{1}\right.$ and $\left.N_{2}\right)$ and ITs (IT 1 , $\mathrm{IT}_{2}$ ). In this example the individuals do not interact. Each individual can reach its IT by combining its intake from the two foods using a different foraging sequence. D. In this example the two individuals are socially attracted and move together from food 1 to food 2. In doing so, none of the individuals can reach their IT. However both can make a compromise to approach an area in the nutrient space minimising the distance between the two ITs (e.g. the collective IT, white circle). (A and B were modified from [14]). 


\section{- - Variance in intake targets ++}

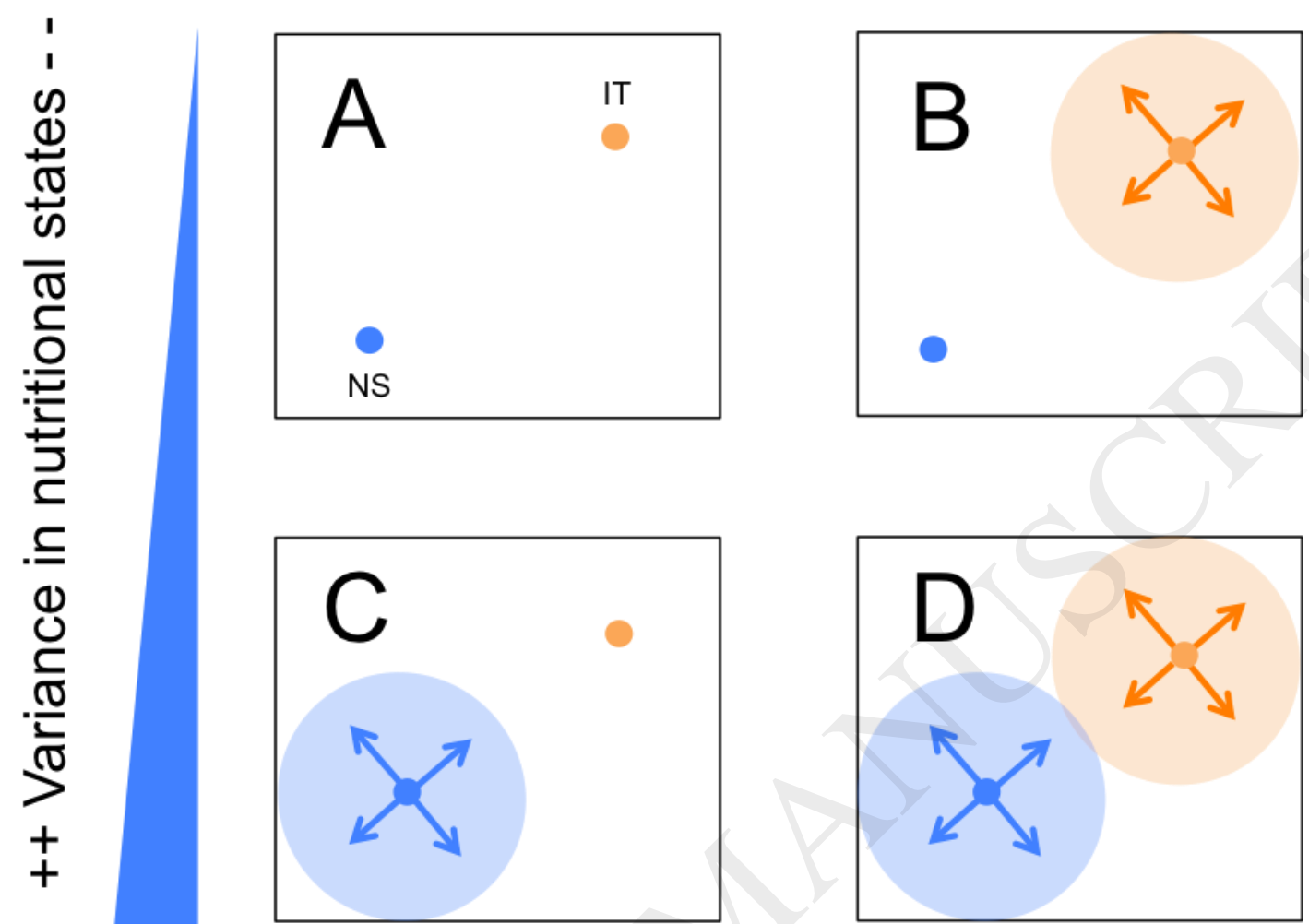

Fig 2. Comparing social interactions based on the nutritional properties of groups (variance in nutritional states, NS, and intake targets, IT). A. Individuals have the same NS and the same IT. This group structure favours collective behaviour (e.g. crickets and locusts, fruit flies, tent caterpillars). B. Individuals have the same NS and different ITs. This group structure is characteristic of host-parasite interactions (e.g. caterpillars, bees) and host-microbiota interactions (e.g. fruit flies). C. Individuals have different NSs and the same IT. This group structure is often associated with behavioural variability characterising temporary roles (e.g. tent caterpillars), and permanent division or labour (social spiders, eusocial bees). D. Individuals have different NSs and different ITs. This group structure is common in species displaying offspring habitat selection (e.g. fruit flies), food provisioning (e.g. eusocial ants and bees) or symbiont farming (e.g. fungus-farming ants). 